\title{
INCOME TAX CONSEQUENCES OF DISTRIBUTIONS OF STOCK RIGHTS TO SHAREHOLDERS
}

\author{
FREDERICK W. WHITESIDE, JR, $\uparrow$
}

SINCE 1937, courts have developed principles of income taxation peculiar to stock rights distributed by corporations to their shareholders. ${ }^{1}$ Resting on several basic assumptions about the inherent nature of such rights, these principles have produced illogical reasoning and uncertain standards in cases con-

$\dagger$ Professor of Law, University of Kentucky. The author wishes to express his appreciation to Professors Boris I. Bittker, Francis W. Coker, Jr. and Leo J. Raskind, who read the manuscript and made helpful suggestions.

1. Not within the scope of this Article, except by way of analogy, are the tax problems of employee stock options and the subscription rights given or sold by the corporation to parties other than shareholders. The type of stock rights under consideration are those which corporations frequently issue to their shareholders affording them the privilege of subscribing to additional stock in the corporation. These subscription rights or privileges are in widespread use; they are variously described as stock rights, stock warrants, stock subscription rights, stock purchase rights or warrants, or stock options. Although the terms "warrants" and "rights" are frequently used interchangeably, different definitions have been advanced to reflect differences of usage in financial circles. "Right" usually denotes the relatively short term privilege issued to stockholders to participate in the purchase of an additional issue of the same class of securities or other securities at a stated price. "Warrant" is used more often as a broader term to describe the privilege frequently issued as an adjunct to another principal security in connection with the original capitalization, or on reorganization; the holder has a long term-sometimes unlimitedcall upon the corporation. See Dewing, A Study of Corporation Securities 414-415 (1934); Shultz, The Securities Market 47 (1946); 2 Dewing, Financial Policy of Corporatrons 1140-1171 (5th ed. 1953); Dodd \& Graham, Security Analysis 569-74 (3d ed. 1951) (option warrants of various types); Berle, Convertible Bonds and Stack Purchase Warrants, 36 Y ALE L.J. 649 (1927) ; Garner \& Forsythe, Stock Purchase Warrants and "Rights," 4 So. CALIF. L. REv. 269, 275 (1931). It does not matter for purposes of our discussion whether subscription privileges are called stock warrants or stock rights.

A less common type of stock right accords to corporate shareholders the privilege of subscribing to stock of another corporation owned by the issuing corporation. Although the emphasis in this Article will be primarily upon the more prevalent stock right to subscribe to the issuing corporation's own stock, the leading Supreme Court case in the field involved subscription rights in stock of another corporation. That case has subsequently been accepted as determinative of the income tax law governing stock rights of both types. See note 14 infra and accompanying text.

The term "stock option" is frequently used interchangeably with "stock right," see, e.g., Choate v. Commissioner, 129 F.2d 684 (2d Cir. 1942), but there is a tendency to use the word "option" more broadly to describe employee stock options and the privilege in the hands of third parties to purchase stock or other property. See, e.g., MontcomerY, FEDERAL TAXES \$11.3 (35th ed. 1954) : "Stock rights are rights normally inherent in stock ownership. Stock options acquired without relation to stock ownership are not stock rights." See note 38 infra for the tax treatment of such options. See also E. T. Weir, 10 T.C. 996,999 (1948), aff'd, 173 F.2d 222 (2d Cir. 1949), pointing out this "fundamental 
cerning the taxability and valuation of stock rights as income. This article will examine the principles and their administrative interpretations and will attempt a fresh approach ${ }^{2}$ under the 1954 Internal Revenue Code and subchapter C regulations on corporate distributions.

As with other corporate distributions to shareholders, the issuance of stock rights is ordinarily preceded by a declaration authorizing the rights to be issued to each shareholder in proportion to his stock on a certain date (usually called the record date). Certificates representing the rights are later issued to the shareholders in the authorized proportion. The holder may then purchase at subscription price a limited number of shares of the specified stock. Issued to raise additional capital, the rights give the shareholders an opportunity to subscribe before outsiders at a price below the current market of the stock, thus insuring success for the subscription. ${ }^{3}$ Rights may normally be exercised by payment of the subscription price after their declaration or issuance and

distinction" between a stock right and an option and holding that the statutory provisions treating the holding periods of stock rights, see text at note 75 infra, applied only to rights, not to options.

For typical forms for stock rights, warrants and fractional warrants, see 2 FLETCHER, Corporation Forms Annotated $\$ \$ 1733-41$ (3d ed. 1938).

Certain stock rights issued pursuant to orders of the Securities and Exchange Commission are not discussed herein, since they are expressly exempted from taxation and present no special problems. INT. REv. CoDE of 1954, $\$ \$ 1081$ (c), 1083(f). For nontaxable rights of this type there is a requirement of apportionment of the cost basis of the original stock between the rights and the stock in proportion to the fair market values of each. INT. REv. Cone of 1954, \$ 1082(c) ; U.S. Treas. Reg. 118, \$ 39.372-2(c) (1953). A loss would be sustained upon lapse by failure to exercise. Spec. Rul., $4 \mathrm{CCH}$ 1947 Stand. Fed. Tax Serv. đ 6113; 1 CCH 1957 Stand. Fed. Tax Rep. f 658.265.

Rights to subscribe to bonds as well as stock are sometimes issued. These have been treated as dividends in property and taxable upon receipt. G.C.M. 13414, XIII-2 CuM. Bull. 124 (1934) ; Spec. Rul., 3 CCH 1941 Stand. Fed. TAX. Serv. 1 6141. Such rights, however, have been ruled non-taxable by the Treasury when the bonds to which they related were convertible into stock of the same kind held by the shareholder and which therefore would be a non-taxable stock dividend. Spec. Rul., 3 CCH 1941 STAND. FED. TAX SERv. If 6480. Accord, Van Nostrand v. United States, 18 F. Supp. 295 (D. Mass. 1937) ; Elvira Scatena, 32 B.T.A. 675 (1935); T. I. Hare Powel, 27 B.T.A. 55 (1932).

Scrip, fractional rights or warrants representing the right of the holder relating to less than a full share also present problems. See Flemcher, Cyclopedia of Corporations $\$ 8977$ (rev. \& perm. ed. 1933) ; I.T. 2392, VI-2 Cunr. BuLl. 17 (1927) (allocation of basis between original stock and scrip).

2. See Bitker, Stock Dividends, Distributions in Kind, Redemptions and Liquidations Under the 1954 Code, 1955 U. So. Calif. TAx Inst. 349, 357.

3. For discussion of whether the shareholders have preemptive rights inherent in their stock ownership and other policy factors governing issuance of rights, see, generally, 2 Dewing, Financial Polici of Corporations 1140-41 (5th ed., 1953) ; Dewing, A Study in Corporation Securities 112 (1934); Fletcher, Cyclopedia of Corporations \$ 8975 (rev. \& perm. ed. 1933) ; Frey, Shareholders' Pre-emptive Rights, 38 Y YLE L.J. 563 (1929) ; Morawetz, The Preemptive Right of Shareholders, 42 HaRv. L. REv. 186 (1928). Typically underwriters guarantee purchase of the non-subscribed portion of the stock issue. On revocability of subscription rights after declaration, see Comment, 39 YaLE L.J. 1163 (1930). 
before a date set for expiration. ${ }^{4}$ Use of subscription rights to raise new capital is widespread, despite occasional criticism of the soundness or necessity of this means of financing. ${ }^{5}$

Determination of the event which produces taxable income from stock rights is made difficult by the courts' misconception of the economic nature of the interest created upon issuance of rights to shareholders. Since this judicial misconception antedates the Internal Revenue Code of 1954 and is not expressly resolved by it, the pre-1954 cases as well as the pertinent language of the 1954 Code will be considered.

\section{The Law Prior to the 1954 Code}

\section{The Taxable Event}

The judicial development of principles peculiar to taxation of stock rights is best understood by a detailed review of three cases treating the consequences of issuance, exercise and sale of stock rights. These principles were developed quite independently from questions of taxability of stock dividends, ${ }^{6}$ for the stock rights cases all involved situations where a distribution of the stock itself would clearly have been taxable as income. ${ }^{7}$

In 1937, the Supreme Court in Palmer $v$. Commissioner 8 held that no taxable income was realized by a shareholder upon the exercise of stock rights.

4. This date may vary widely, and there may also be other conditions or restrictions upon exercise.

5. Corporations listed on the New York Stock Exchange raised two billion dollars during 1956 through the offering of subscription rights to holders of common stock. The Exchange, April 1957, p. 9.

See 2 Dewing, Financial Policy of Corporatrons 1160, 1163 (5th ed. 1953), which points out the dilution of stockholders' equity through the practice.

6. The difficulties surrounding the taxability of stock dividends caused much litigation prior to the 1954 Code and have been widely discussed. See, e.g., Lowndes, The Taxation of Stock Dividends and Stock Rights, 96 U. PA. L. REv. 147 (1947) ; Rottschaefer, Present Taxable Status of Stock Dividends in Federal Law, 28 Mrnn. L. Rev. 106 (1944).

To the extent that the difficulties have been eliminated in the 1954 Code by congressional renunciation of intention to tax, see Bittker, supra note 2.

7. See, e.g., Palmer v. Commissioner, 302 U.S. 63 (1937). When the stock itself was not taxable attempts to tax stock rights failed. See Charles M. Cooke, Itd., 2 T.C. 147 (1943) (since preferred stock issued to common stockholders was non-tasable, the rights could not be taxed either upon receipt or exercise) ; Miles v. Safe Deposit \& Trust Co., 259 U.S. 247 (1921) (dictum). Consequently, stock rights issued prior to June 22, 1954, the effective date of the 1954 corporate distributions provisions, INT. REv. Cone of $1954, \S 391$, created the same uncertainties as stock dividends. The line of demarcation between taxable and non-taxable rights is determined by the taxability as a dividend of the stock offered in the right, subject to the added hurdle for stock rights of principles announced in Palmer v. Commissioner, supra. See also Magill, Taxable I nconse 59-62 (rev. ed. 1945).

8. 302 U.S. 63 (1937), 51 HaRv. L. Rev. 515 (1938), 86 U. PA. L. Rev. 317 (1938).

When Palmer reached the Supreme Court, the taxability of stock rights issued to shareholders to buy stock in another corporation had caused a conflict in the circuits. Holding taxable upon receipt by shareholder: Ramapo, Inc. v. Commissioner, 84 F.2d 986 (2d Cir. 
The corporation had distributed to its shareholders pro rata a series of fifteenday rights to subscribe to shares of stock which it owned in another corporation. Despite a showing in the record that the underlying stock was selling at about twice the subscription price when the rights were delivered and that the rights themselves had established market values on a stock exchange, the Supreme Court sustained the Tax Court's finding of fact that the corporation intended only a sale of stock to shareholders at fair value. The "transaction-in form a sale-was not intended to be the means of a distribution of earnings to shareholders" and could not be converted into a taxable dividend by the fact that the value of the shares was higher than the subscription price. ${ }^{10}$ Therefore, the Court reasoned, the exercise of the rights was an acceptance of the corporation's offer to sell which did not give rise to taxable income.

The Court, by way of dictum, further said that the "mere issue of rights to subscribe and their receipt by stockholders" could be neither a "dividend"11 nor a "distribution of corporate assets or diminution of the net worth of the corporation,"

"[since the rights] are at most options or continuing offers, potential sources of income to the stockholders through sale or the exercise of the rights. Taxable income might result through their sale, but distribution of the corporate property could take place only on their exercise."12

But even the exercise of the rights was not a distribution in this case, for the corporation was committed to the sale "by appropriate corporate action" when the sale price represented the reasonable value of the shares.

1936) (rights constituted taxable dividend to extent of their value when made available to the shareholder, since the corporation had undistributed earnings and profits sufficient to cover the distribution), 31 ILL. L. REv. 537; Commissioner v. Mayer, 86 F.2d 593 (7th Cir. 1936), rev'd (on authority of Palmer), 302 U.S. 647 (1937). Holding not taxable either on receipt or exercise: Helvering v. Bartlett, 71 F.2d 598 (4th Cir. 1934) (issuance of the option was not a distribution within statutory definition of a dividend, and acceptance of the option by exercise merely merged the continuing offer of the option into the contract of purchase resulting from acceptance), 41 W. VA. L.Q. 93 (1934); see also Commissioner v. Cummings, 77 F.2d 670 (5th Cir. 1935).

An earlier Supreme Court case, Miles v. Safe Deposit \& Trust Company, 259 U.S. 247 (1921), involved rights issued pro rata to shareholders to subscribe to a new issue of the corporation's own common stock. The rights were not taxable because distribution of the stock itself fell within the concept of a non-taxable stock dividend under the law prevailing at that time. Nevertheless the Court considered the rights a mere privilege or equity to the shareholders to participate in contributing new capital to the corporation, not a distribution to them of profits. Id. at 252 .

9. 302 U.S. at 70.

10. But the Court admitted that such a sale at a bargain may sometimes amount to a distribution of profits to shareholders, to the extent of the difference between the value of the shares purchased and their subscription price. 302 U.S. at 69 .

11. 302 U.S. at 70. The word "dividend" was then defined by the Revenue Act of 1936, $\$ 115$ (f), 49 Stat. 1688. Minnie T. Grippin, 36 B.T.A. 1109 (1937) (rights to buy shares of stock in another corporation, with no value at time of issuance) is in accord with the Palmer dictum as to non-taxability of stock rights upon issuance.

12. 302 U.S. at 70 . 
In Choate v. Commissioner ${ }^{13}$ the Second Circuit applied Palmer principles to the exercise by shareholders of rights to subscribe to the issuing corporation's own stock ${ }^{14}$ and followed the Palmer dictum that income could never be realized by receipt of rights alone. The rights had substantial market value when received by the taxpayer, but were worth much less when exercised near their expiration date. The event giving rise to income taxable to the shareholder was held to be the exercise of the rights and the tax was measured by their value at that time. The reasoning was that the distribution of earnings by the corporation to its shareholders took place at the time of exercise of the rights. ${ }^{15}$ Here, unlike Palmer, the court found an original intention to distribute corporate earnings to shareholders and not merely to offer them an opportunity to buy stock from the corporation. Judge Frank, writing for the court, interpreted the Palmer requirement of corporate intention to make a distribution of earnings to mean an "objective" intention which he found in the issuance of rights having real value. ${ }^{16}$

The opinion also suggested the tax result when the value of rights changed between the time of receipt and exercise. If the rights appreciated between issuance and exercise, the taxable amount would be limited to their value when issued; if they declined, only their value when exercised could be taxed, for

13. 129 F.2d 684 (2d Cir. 1942).

14. The court expressly adopted the principle that shareholders could realize no income from receipt of subscription rights, but only potential dividends. 129 F.2d at 687 . Whether the rights related to the subscription of stock in the issuing corporation or in another corporation was considered immaterial since the stock to which the rights related qualified constitutionally as a taxable stack dividend, and there were ample earnings and profits in the corporation's hands to cover the shareholder's ratable portion of the distribution. This situation is assumed throughout this discussion.

On the difference between stock in the issuing and another corporation, see an earlier case in the same circuit, Metcalf's Estate v. Commissioner, 32 F.2d 192, 194 (2d Cir. 1929), holding that a distribution of the assets of a corporation in cash or in stock of a different enterprise is a dividend (unlike a stock dividend in the issuing corporation, which was exempted from taxation at that time). See Moran v. Lucas, 36 F.2d 546 (D.C. Cir. 1929), 43 Harv. L. Rev. 1157 (1930) ; B. F. Saul, 4 B.T.A. 639 (1926). This distinction between stock rights in the issuing corporation's stock and another corporation's stock seems sound. See Brief for Appellee, p. 17, Palmer v. Commissioner, 302 U.S. 63 (1937). But the difficulty created by the Palmer conception of the nature of stock rights seems to prevent proper evaluation of the tax effect of issuance of rights of both types. If income is realized by the issuance of subscription rights in the issuing corporation's stock, the same result would necessarily follow with regard to stock rights in another corporation's stock.

15. 129 F.2d at 687 . The court viewed the exercise of the favorable option (i.e. rights) as an acceptance by the stockholder of "the corporate offer, embodied in the option, intentionally to distribute corporate earnings." The rights were actually exercised by members of the stockholder's family to whom he gave them, but the stockholder himself was taxed under the principle of Helvering v. Horst, 311 U.S. 112 (1940).

16. 129 F.2d at 686. This value, according to both the Choate and Palmer opinions, consists in and is measured by the so-called spread, the difference between the fair market value of the stock and the subscription price at the time the valuation is made. See text at note 45 infra. 
that would be the limit of the actual distribution. The result is curious: although distribution by the corporation may not take place before a shareholder's exercise of rights, both taxability and taxable value are determined by facts existing at the time the corporation issues the rights. ${ }^{17}$

Both Choate and Palmer held that stock rights were taxable only as dividends, if at all. The contention that stock rights should be taxable under the broad provision of section 22 (a) without regard to the statutory definition of "dividends" was rejected in the Choate case on the ground that distributions of rights were referred to only in the statutory provisions affecting dividend distributions. ${ }^{18}$ And on the authority of the Palmer and Choate cases, together with Helvering $v$. Horst, ${ }^{19}$ the court had no trouble in finding that dividend income was realized upon sale of rights in Gibson $v$. Commissioner. ${ }^{20}$ The rights to subscribe to stock in the issuing corporation had substantial value when received by the shareholders, and the sale price was slightly higher still. The court held the sale of rights a realization of income by analogy to Helvering v. Horst, even though upon receipt the taxpayer had only "an option to obtain a distribution by exercise." Although the sale of stock rights by a shareholder, like the exercise, would seem to constitute a realization of income to him, it is difficult to view the sale by the shareholders as a distribution by the corporation. Nevertheless, that portion of the sale price representing the market value of the rights when received was treated as ordinary income. Since neither the taxpayer nor the Commissioner had challenged the inclusion of the balance of the sale price as capital gain, the court found it unnecessary to decide whether this balance could have been taxed as ordinary income.

The Treasury Department, however, has since taken the position that the entire amount received upon the sale, not merely the value of the right when received, is taxable as ordinary income. ${ }^{21}$ This position appears irreconcilable with Treasury approval, in the same ruling, of the Choate principle that only

17. That the absence of a spread at time of exercise, despite spread at issuance, would have precluded any tax under Choate, see Lowndes, supra note 6 , at 165 .

18. 129 F.2d at 689 . The dividend provisions may be found in Int. Rev. Code of 1939, $\S \S 115(\mathrm{a}), 115(\mathrm{f})(1-2), 53$ STat. $46-47$.

19. 311 U.S. 112 (1940) (owner of bonds taxed on interest as income, although he had given away coupons shortly before they matured).

20. 133 F.2d 308, 309 (2d Cir. 1943), appcal dismissed, 320 U.S. 805 (1944). The shareholder was not allowed to escape realization of the income by selling the rights instead of exercising them. See also Commissioner v. Cummings, 77 F.2d 670 (5th Cir. 1935). Cf. Choate v. Commissioner, 129 F.2d 684 (2d Cir. 1942) (gain upon exercise tased to shareholder who had given rights to members of his family who later exercised them). The court in Choate also rejected the argument that gain upon the sale of a right instead of its exercise might be taxable under the broad language purporting to tax all income "from whatever source derived," without reference to the dividend provision contemplating a distribution of corporate earnings. Int. Rev. Code of 1939, $\$ 22(\mathrm{a}), 52$ STAT. 457 (now INT. Rev. CODE of 1954, \$ 61 (a)).

21. G.C.M. 25063, 1947-1 Cuar. Butl. 45 (1947). See also Spec. Rulings, 4 CCH 1947 Stand. Fed. Tax Rep. \f 6099 (1946), 4 CCH 1947 Stand. Fed. TaX Rep. đf 6098 (1946). 
the value when issued is taxable to the shareholder who exercises appreciated rights. If the increase in value of rights between issuance and exercise is not considered part of the intended dividend, it cannot reasonably be argued that a similar increase prior to sale should be treated differently. The ruling does clearly acquiesce in the principle of the Palmer and Choate decisions that income is realized only upon exercise or sale of stock rights, not by mere receipt, ${ }^{2 \cdot 2}$ and in the additional principle of the Choate decision that valuation should be determined at receipt or at exercise, whichever is lower.

At least six dates on which stock rights may be said to result in income to the shareholder appear possible. ${ }^{23}$ These are: (1) the date of declaration of rights by the corporation; (2) the date of record, when the shareholders entitled to receive rights are determined by reference to the corporation's books ; (3) the date when rights first become available to shareholders ; ${ }^{24}$ (4) the earliest date on which the rights can be exercised $;^{25}$ (5) the actual date of exercise or sale; and (6) the date when stock purchased through exercise of rights is finally sold. ${ }^{26}$ In holding that income can never be realized by the shareholder upon the mere issuance of rights, Palmer rejected the first three of these possible dates and permitted taxation at exercise or sale, subject to certain conditions. When the corporation has no intention of making a distribution at the time of issuance, a necessary factual conclusion when the rights have no initial value, the Palmer doctrine prevents taxation of the rights as income even upon exercise or sale. Thus only the sixth date-that of sale of the stock acquired

22. Since courts conceived that the nature of stock rights prevented taxation in the absence of exercise or sale, it followed that lapse or expiration of rights produced no tax consequence of any kind. See text at note 64 infra.

23. See 47 Y ALE L.J. 139 (1937).

24. Several commentators take the position that a tax to the shareholders upon receipt of stock rights at their fair value at that time is both constitutional and desirable. See Lowndes, supra note 6, at 157-70; Notes, 47 YaLE L.J. 139, 142 (1937); 51 Harv. L. Rev. 515, 519-20 (1938) ; 31 ILE. L. REv. 537, 540 (1936). See also Lincoln, Stack Dividends and Stock Rights, 27 TAXes 109, 111 (1949). But cf. Note, 51 CoLUn. L. Rev. 496, 507 (1951).

"Time of issuance" and "time of issue" have sometimes been used synonymously by courts and writers alike, apparently to denote the date of distribution. The term "date of issue" carries a possible ambiguity for it could also mean the time of the corporate action authorizing the rights. "Time of issuance" should mean the time when the corporation makes the distribution. See U.S. Treas. Reg. $\$ 1.301-1$ (b) (1955) for an example in which the date of distribution by the corporation was in a different taxable year from the date of receipt by the shareholder. Since the tax is upon the shareholder, the time for inclusion in income is the date of actual receipt, or availability to him, of the dividend, Avery v. Commissioner, 292 U.S. 210 (1934), although valuation is determined as of the date of distribution. INT. REv. CODE of 1954, § 301 (b). The word "receipt" will be used herein wherever possible.

25. The Supreme Court in Palmer recognized this as a possible alternative, although in fact the rights were exercisable as soon as they were received. 302 U.S. at 68 . See also Brief for Appellee, pp. 31, 40, Palmer v. Commissioner, 302 U.S. 63 (1937).

26. A possible variation might recognize the rights as income at issuance to the extent of their existing value, any increased value upon exercise or sale becoming additional income at the latter time. 
through exercise of the rights-is left for possible realization of income in the form of capital gain. ${ }^{27}$

What are the merits in the judicially developed principles that taxable income is never realized by the mere issuance of stock rights to the shareholder, and that taxable income may be realized by the shareholder's subsequent exercise or sale of the rights only if there is corporate intention to make a distribution at the time of issuance? Financial literature and practice attach monetary value to stock rights as soon as they are declared for the benefit of those listed as shareholders on the record date. ${ }^{28}$ The rights may usually be sold or traded on an exchange, but, prior to the issuance of certificates, a shareholder may sell rights only on a "when, as, and if issued" basis, subject to certain restrictions. .9 Since the rights are not fully transferable before the certificates are printed, issued and delivered to the shareholder, practical difficulties prevent their valuation for tax purposes upon either the declaration or record date. Frequently, corporations expressly reserve the power to withdraw or change their plans to issue rights prior to actual issuance. Even if this power is not so reserved, the possibility remains that rights will be held revocable prior to issuance. $^{30}$

Upon receipt of the certificates, however, the shareholder has rights with ascertainable value which may be transferred without restriction. The rights have value independently of the underlying stock, which shortly before the record date is usually selling separately from the rights on the exchanges. Taxing the rights to the extent of their fair market value upon delivery to the shareholder would be consonant with the general principle of tax accounting which taxes dividends upon receipt. ${ }^{31}$ And most commentators have taken the position that actual receipt is the most logical time for imposition of the tax. ${ }^{32}$

27. A capital gain might be realized upon sale by the shareholder or by a transferee with a substituted basis. See, e.g., INT. REv. CoDE of 1954, $\S 1015$. Whether the gain or loss thus realized is long or short term depends upon the holding period computed from the date the stock was acquired by exercise of rights. Id. $\$ 1223(6)$, discussed in text at note 77 infra. Of course, if the transferee had acquired the stock from the original stockholder with a new basis-e.g., acquisition after his death-the basis would be the fair market value at death (id. $\S 1014$ ), and the holding period would likewise begin with the date of such acquisition.

28. 2 Dewing, Financial Policy of Corporations 1157-62 (5th ed. 1953).

29. See, e.g., New York Stock Exchange Rule 550(d) (3) and explanation, P.E.-351; 47 YALE L.J. 139, 140 (1937).

30. See Comment, 39 Y ALE L.J. 1163 (1930). There are no cases directly in point. To the effect that a stock dividend is revocable, Staats v. Biograph Co., 236 Fed. 454 (2d Cir. 1916) ; Terry v. Eagle Lock Co., 47 Conn. 141 (1879) ; Stevens, Corporatrons 460 (2d ed. 1949).

31. Avery v. Commissioner, 292 U.S. 210,215 (1934) (dividend checks not "unqualifiedly subject to the petitioner's demand" until received on January 2 , in the calendar year following the year of mailing on December 31). But a taxpayer would not be allowed to defer his dividend income until his next taxable year by requesting the corporation to delay sending his dividend check. A doctrine of constructive receipt is applied. Frank W. Kunze, 19 T.C. 29 (1952).

32. See note 24 supra. Taxation of rights as ordinary income upon receipt, it has 
The holding in Palmer v. Commissioner that no income was realized upon issuance to the shareholder might be justified as an acceptance of the Board's finding of fact that the rights had no value when issued. ${ }^{33}$ But the dictum, since accepted as law, that income is never realized upon issuance by reason of the nature of stock rights ignores the fact that the rights themselves have a readily ascertainable market value. ${ }^{34}$ The Court adopted two related premises about issuance of stock rights: (1) issuance constitutes merely a continuing offer of sale by the corporation to the shareholders; and (2) no diminution of corporate assets results from issuance. The first statement overlooks the economic reality that rights are transferable and have market value. The second seems no more than an afterthought induced by the Court's view that rights constitute only an offer of sale. In reality, when a corporation distributes rights to subscribe to stock in another corporation, the corporate assets are reduced at distribution to the degree that there is a spread at that time between market and subscription price. ${ }^{35}$ Although the corporation sacrifices its own interest in any future increment in the stock's value above subscription price, the real diminution, if any, takes place at the time of distribution when actual rather than speculative assets are reduced. And when the corporation distributes rights to subscribe to its own stock, which is not carried as an asset, no diminution or write-down of the corporate assets can ever occur. ${ }^{30}$ Moreover, diminution of corporate assets is, in all cases, irrelevant to whether or not the rights represent income to the shareholder.

Again, the cases have developed the questionable principle that even the exercise of rights is not a taxable event unless there is a corporate intention to make a distribution of earnings. The courts' tendency to view the transaction primarily as a sale to the shareholders may lie behind this notion, for Palmer indicated that it might be the government's responsibility to show corporate intention when the transaction is "on its face a sale." 37 But the tax is imposed upon the shareholder and is based upon his realization of income from investment in the corporate enterprise. The intention of the corporation appears irrelevant even where undistributed corporate earnings and profits are sufficient to cover the shareholder's ratable portion of the distribution. Moreover, the corporate intention requirement places a premium on window dressing which clothes the transaction in the form of an offer of sale by the corporation to the shareholders.

been suggested, eliminates the possibility of loss of revenue through expiration of rights without exercise. See 47 YaLE L.J. 139, 142 (1937).

33. 302 U.S. at 68. See Lowndes, supra note 6 , at 159-60.

34. See 2 Dewing, Financial Policy of Corporations 1160-61 (5th ed., 1953) (describing the realization of money by sale of the rights, or, sometimes, by short sale of stock).

35. 47 Yale L.J. 139, 142 (1937).

36. Bittker, supra note 2, at 357. Where there is a distribution of rights to subscribe to stock in the issuing corporation, in actual accounting practice a charge against surplus rather than a write-down of assets would probably be made. Note, 51 Coluar. L. REv. 496, 498 (1951).

37. 302 U.S. at 69. 
But if corporate intent is relevant, its meaning in this context is still indefinite. The corporation usually has two purposes in distributing rights to subscribe to stock. The first is admittedly to raise new capital; but the desire to benefit the shareholders indirectly by enabling them to subscribe to new stock at an advantageous price is often an additional factor. The exercise of stock rights obviously involves a sale in that the shareholder receives new shares for the subscription price. Frequently the subscription price is almost as high as the market value of the stock, and the shareholders' benefit is relatively small; in this context a simple purchase and sale approach might be justified. But the differential between market value of new shares purchased and subscription price is the measure of a bargain, in the sense of economic benefit. Furthermore, if the shareholder chooses not to subscribe, he may sell the rights themselves. This independent value of rights on the exchange exposes the fallacy of a simple purchase and sale approach.

Employee stock option cases provide an analogy. ${ }^{38}$ At one time courts refused to find a taxable event in the exercise by an employee of a favorable stock option, unless the option was intended as compensation. If the option was interpreted merely as an opportunity to purchase a proprietary interest in the corporation, no tax was assessed. ${ }^{39}$ But recent Supreme Court pronouncements have reduced the emphasis upon the purchase aspect of the exercise of rights and view the compensatory element of the bargain purchase realistically as income.0 In Commissioner $v$. LoBue ${ }^{41}$ an express corporate intent to confer a proprietary interest did not deter the court from finding the option taxable as compensation. Judicial disregard of corporate intent in this context suggests similar de-emphasis of the sale element in the purchase of stock through the exercise of rights.

38. The type of stock options under discussion are those not qualifying as "restricted stock options" under INT. REv. CODE of 1954, $\S 421$. The general principles of income under $\S 61$ (a) (1) are applicable to the non-qualifying type. For complete discussion of both types of options, see Rudick, Executives' Compensation, Inchuding Stock Option Arrangements Under the 1954 Code, 1955 U. So. CaLIF. TAX Inst. 655. See also Lyon, Enployec Stock Purchase Arrangements, 31 TAXEs 1021 (1953) ; Lyon, Employee Stock Options Under the Revente Act of 1950, 51 Colunr. L. Rev. 1 (1951). Compare $\$ 305$ (c) with $\S 61$ (a) (1) in the 1954 Code for distributions which may have the effect of compensation.

39. See, e.g., Abraham Rosenberg, 20 T.C. 5 (1953); Norman G. Nicolson, 13 T.C. 690 (1949) ; cases collected in Rudick, supra note 38, at 700-24. Rudick concludes that many factors bear upon whether the option is "compensatory" or "proprietary," no single factor being conclusive. Transferability is a normal feature of rights distributed to shareholders not usually present in employee stock options. For valuation difficulties when options are non-transferable or subject to restrictions, see note 42 infra.

On the similarity between stock option and stock rights cases, compare the language "sales of ... assets to stockholders at fair value," Palmer v. Commissioner, 302 U.S. 63, 71 (1937), with intention to confer a "proprietary interest," Commissioner v. LoBue, 351 U.S. 243,245 (1956).

40. Commissioner v. LoBue, 351. U.S. 243 (1956) ; Commissioner v. Smith, 324 U.S. 177 (1945). Both cases referred to Palmer with apparent approval.

41. 351 U.S. 243 (1956). 
The employee cases also by analogy support the view that stock rights may constitute income upon receipt even without exercise. In the LoBue case the taxable event was deferred until the employee exercised his option, because the particular options under consideration were not transferable by the employee and were restricted in other respects. But the court recognized the possibility that a valuable option may be compensation at the time of receipt:

"It is of course possible for the recipient of a stock option to realize an immediate taxable gain. See Commissioner v. Smith .... The option might have a readily ascertainable market value and the recipient might be free to sell his option."42

Two Justices viewed "the taxable event as the grant of each option, not its exercise," and another recent case recognizes the receipt by the employee of the option as the taxable event. ${ }^{43}$

Admittedly, taxability of employee stock options depends upon the finding of compensation under the broad statutory definition of income, ${ }^{44}$ whereas taxability of distributions to shareholders is dependent upon the finding of a dividend under the corporate distribution provisions. Yet there is no reason for conflicting views about the occurrence of the taxable event.

\section{Valuation}

Whether receipt or exercise of stock rights constitutes the taxable event is a determining factor in the problem of time and manner of valuation. Unless the difficulties in determining the value of stock rights at issuance is a valid policy rationale in favor of deferring the taxable event until exercise, considerations of fairness militate against such postponement. Courts and writers have usually assumed that the value of rights is determined by the spread, or excess of the fair market value of the stock over the subscription price, determined as of the time the valuation is made.45 Use of the spread, however, amounts only to a determination of the bargain element in the share-

42. 351 U.S. at 248. Non-transferability and restrictions upon employee options may give rise to valuation difficulties not present in the shareholder cases. See Note, 62 Yare L.J. 832 (1953); Comment, 21. U. CHI. L. Rev. 464 (1954).

43. 351 U.S. at 250 (concurring and dissenting opinion). See Commissioner v. Stone's Estate, 19 T.C. 872 (1953), aff'd, 210 F.2d 33 (3d Cir. 1954), 64 YALE L.J. 269 (1954).

44. INT. Rev. CODE of 1954, § 61(a). See cases collected in Rudick, supra note 38, at $700-24$.

45. Choate v. Commissioner, 129 F.2d 684 (2d Cir. 1942) speaks only of the spread in discussing the value of rights, whether determined at the time of issuance or exercise. See W. G. Maguire, 20 T.C. 20 (1953) ; Lowndes, supra note 6, at 159, 163. But cf. Note, 51 Colcu. L. REv. 496, 507 (1951) (effective method of taxing at issuance must be "upon valuation, rather than spread").

If the subscription price should be greater than the market price of the stock there would be a negative spread, so that the value of the rights would be zero on the assumption that value is measured by spread. It is conceivable that the rights might have value even in this situation. See Commissioner v. Stone's Estate, 19 T.C. 872 (1953), aff'd, 210 F.2d 33 (3d Cir. 1954). 
holder's investment when he buys the stock. But the market value of the stock rights themselves is the real object of valuation. Although the spread will usually approximate the market value of the rights, many additional factors may be overlooked by application of the spread test alone. Among these are prospects for expansion and growth in the particular corporation and in the industry, the fluctuating or stable nature of the price range of the stock, the length of time permitted for the exercise of rights ${ }^{46}$ and of course the trend of the economy generally. Although traditional formulas for determining the value of a stock right before exercise are based upon the market value of stock and the subscription price, recently additional and more comprehensive formulas have been suggested to take account of some other variables. ${ }^{47}$ Nevertheless, all recognize that the actual market value may differ from the theoretical value computed under the formulas. ${ }^{48}$ Treasury regulations under the 1954 Code clearly consider the possibility that market value of rights is sometimes less than the spread. ${ }^{40}$ It is even possible for rights to have value when received by the shareholder although the stock is worth less than the subscription price. ${ }^{50}$

46. 2 Dewing, Financial Policy of Corporations 1157-58 (5th ed. 1953); 47 Yale L.J. 139 (1937).

47. 2 Dewing, Financlat Policy of Corporatrons 1158 (5th ed. 1953).

Traditional formulas are set out in $i d$. at 1208. Badger, Investarent Principles and Practices 741 (1935); Livermore, Investment Principles and Analysis 33 (1938). A more complete treatment of factors in the valuation of rights appears in Evans, The Theoretical Value of a Stock Right, 10 J. Finance 53 (1955), where two formulas are wffered for estimating the value of rights more accurately than under traditional practice. One is to be used when stock prices are assumed to be determined by earnings and the sccond when dividends are assumed to be the determining factor. Although a combination of formulas may be used in determining the theoretical value of a right to help the corporation decide upon the optimum subscription price, the actual value upon issuance must be determined differently.

48. 2 Dewing, Financial Policy of Corporations 1158-59 (5th ed. 1953) points out reasons for differences between market and theoretical values.

49. U.S. Treas. Reg. $\$ 1.307-1$ (b) (1955), under the 1954 Code provision concerning the allocation of the original basis of stock between the stock and the rights in proportion to the fair market values of each at the time of distribution. An example is given in which the fair market value of one right is $\$ 19$, but the "spread" is $\$ 20$ (the fair market value of one share, ex-rights, being $\$ 110$ and the subscription price $\$ 90)$.

50. In Commissioner v. Stone's Estate, 19 T.C. 872 (1953), aff'd, 210 F.2d 33 (3d (ir. 1954), Graham \& Dodd stock purchase warrants were issued to the corporation's president who paid $\$ 1000$ for them. The warrants specified a subscription price greater than the market value of the stock. The president nevertheless paid ordinary income tax on $\$ 5000$ ( $\$ 6000$ less the $\$ 1000$ consideration paid) in that year, treating the warrants as income in the form of compensation. In a later year he sold the warrants for $\$ 82,680$, claiming a capital gain for the excess of sales price over basis. The Third Circuit agreed with the Tax Court that the rights were properly declared as income in the year received. Thus it may sometimes work to the taxpayer's advantage to pay the tax upon the value of rights or options when received. Opportunities for tax reduction, avoidance or evasion are also suggested. Rights, especially those of a small corporation, might be issued and taxes paid early in the history of the enterprise when the shares are depressed or un- 
Courts have readily determined the fair market value of rights at time of exercise to be the value of the stock received minus the subscription price. Although this solution may be an easy rule of thumb for practical purposes, it does not make the rights themselves the subject of valuation for income tax purposes, but rather their exercise, considered as the distribution in the form of the bargain portion of the shareholder's subscription purchase. If the market value of the rights immediately prior to exercise may be less than the market value of the stock minus subscription price,, 51 the theory of taxation is necessarily based upon the bargain element of the purchase rather than upon the value of the rights, in so far as the spread exceeds the market value of the rights. Clearly, the propriety and fairness to the taxpayer of this procedure is questionable.

A more appropriate theory would tax the rights themselves, valued at the time they are first made available to the shareholder. Valuation at the time of distribution permits valuation data to be collected for a single time; choice of exercise or sale requires valuation at many different times for different stockholders. There are no insurmountable difficulties in valuation, even though rights are frequently issued as part of a series at different times and are usually of short term duration. ${ }^{52}$ Unlike employee stock options, rights are commonly issued by public corporations to large numbers of shareholders; they usually have a ready market, and are quoted on the exchanges, and are not subject to the same types of conditions and restrictions. In the absence of a ready market, no greater valuation difficulty exists than that for other types of property, where all relevant circumstances must be considered.

\section{The Effect of the 1954 Code Provisions}

\section{The Taxable Event}

The 1954 Code contains no provisions specifically directed to a solution of the problems raised by Palmer and Choate, and leading tax authorities have continued to treat the pre-1954 decisions as determinative. ${ }^{63}$ Nevertheless,

marketable and the rights appear to have no value. Perhaps a tax upon exercise or upon issuance with an additional tax upon the increase in value between issuance and exercise or sale would partially solve this problem. But the final solution is only to be found in a wholesale reform of capital gains principles.

51. U.S. Treas. Reg. $\S 1.307-1$ (b) (1955). See 2 Dewing, Financial Policy of Corporations 1209 (5th ed. 1953).

52. The last factor may even simplify valuation since only records of market price over the shorter periods need be maintained.

53. "It is important to note in this connection that the mere receipt of rights to purchase corporate assets, even at a favorable price, does not result in income. There is no income, in any event, unless the rights are exercised or sold or otherwise disposed of." (emphasis added.)

2 Mertens, Feneral Income Taxation $\$ 11.09$ (rev. ed. 1955). Palmer is cited to support this proposition. See 1 P-H 1957 Fed. TAX SERv. If 9420, 9424B. Cf. earlier treatment in Magill, Taxable Inconse 59-62 (rev. ed. 1945). 
subchapter $C$ and the regulations do contain language relevant to these problems.

The pre-1954 principles were applied with equal effect to rights permitting subscription to stock in the issuing corporation and to stock in another corporation. ${ }^{54}$ In one significant respect the 1954 Code differentiates between the two kinds of rights. A special exclusion now affects both stock and rights to acquire stock in the issuing corporation. The general rule of section 305 (a), following the pattern of stock dividends, excludes such stock rights from taxability. Two exceptions in 305 (b) are designed to tax distributions when they are in effect "in lieu of money," that is, (1) to the extent that the stock or rights distributed are in discharge of preference dividends for the taxable year or for the preceding taxable year, or (2) when distribution is at the election of any shareholder payable in other property instead. If either exception applies, the distribution of stock rights "shall be treated as a distribution to which section 301 applies."56 By excluding from taxable income most distributions of stock rights in the issuing corporation's stock, the Code greatly narrows the area in which problems of the taxable event and the time for tax valuation can arise. But rights in the issuing corporation's stock taxable under section 305 (b) and rights to subscribe to stock of another corporation preserve the old difficulties.

Stock rights to subscribe to stock in a corporation other than the issuing corporation and rights to subscribe to stock of the issuing corporation excepted by section 305 (b) are governed by section 301 , the general provision dealing with corporate distributions to shareholders when the specific provisions in subchapter $C$ do not apply. Section 301(b) defines the amount of distribution to individuals as the "money received, plus the fair market value of the other property received."5r It also provides that the fair market value shall be determined "as of the date of the distribution." This clause justifies an inference

54. In the cases dealing with stock rights of both types, the stock itsclf would bave been taxable if distributed to the stockholders. A distribution of stock of another corporation is taxable under well-established principles. See Peabody v. Eisner, 247 U.S. 347 (1918). To hold stock rights in the issuing corporation taxable, the same requirements for a constitutionally taxable stock dividend had to be satisfied, sce Eisner v. Macomber, 252 U.S. 189 (1920); Koshland v. Helvering, 298 U.S. 441 (1936), as for a distribution of the stock itself. The cases discussing stock rights were cases in which these requirements were met; there were also undistributed earnings and profits in the corporation sufficient to cover the shareholder's ratable proportion of the distribution. See note 14 supra.

55. INT. Rev. Code of 1954, § 305 (a). See S. Rep. No. 1622, 83d Cong., 2d Sess. 241 (1954). The purpose of the new provision was to elininate such problems as whether the proportionate interest of the shareholder in the corporation is altered, sce Koshland v. Helvering, 298 U.S. 441 (1936), by ending the taxation of stock dividends and rights to the shareholder in most cases. See 2 ALI Fed. Ixcosre TAx STAT. $\$ \S 25510, x 51.1$ (Feb. 1954 Draft), providing similar treatment for stock and rights, but limiting the blanket exclusion to distributions on common stock.

56. INT. REv. CODE OF 1954, § 305(b).

57. Corporate distributees are taxed on the fair market value of the property received or its adjusted basis in the hands of the distributing corporation immediately prior to the distribution, whichever is lower. Id. § 301 (b)(1)(B). 
that the taxable event for any "property received" will be its receipt, and that its value may be fixed at the time of distribution. The regulations are consistent with the statute: they specify that distribution amounts are includible in shareholders' gross income when "unqualifiedly made subject to their demands."

Additional language in the statute departs from the Palmer principle that income never results from the mere issuance of stock rights. Section 305(b) expressly classifies all taxable stock rights as "property," a description inconsistent with the view that prior to exercise they are mere offers to sell. The tax treatment in section 301 is made applicable to distributions of property defined in section 317 (a) as "money, securities and any other property except stock in the corporation making the distribution (or rights to acquire such stock)." This definition clearly includes stock rights in another corporation's shares. And section 305 (b) provides that if rights to buty the issuing corporation's stock fall into either of the listed exceptions, they "shall be treated as a distribution of property to which section 301 applies." 60 Thus, all taxable stock rights are expressly made property for purposes of the statute.

Further, the purpose of issuing stock rights in shares of the distributing corporation in lieu of current dividend preferences suggests the propriety of taxing the rights as dividend income to the extent of their value at issuance, ${ }^{01}$ And when the tax arises from an option in the shareholders to take cash or other property in lieu of rights, there can be no doubt of the statutory intention to tax the value of the rights upon receipt even though they may never be exercised. ${ }^{62}$

Not only is the statutory language inconsistent with the view that the nature

58. U.S. Treas. Reg. $\S 1.301-1$ (b) (1955). The quoted language arose in conncetion with the constructive receipt cases where a cash basis taxpayer must report income cven prior to its actual receipt. Weil v. Commissioner, $173 \mathrm{~F} .2 \mathrm{~d} 805$ (2d Cir.), cert. denicd, 338 U.S. 821 (1949). See Comment, 45 ILl. L. REv. 77 (1950). The Regulations also demon1strate the possiblity of a different and possibly later date for valuation than for inclusion in income, by prescribing that the fair market value of the property shall be determined "as of the date of the distribution." In an example cited, the "distribution" by the corporation is on the last day of December in the taxpayer's calendar year but is not received until January 2 of the following year. The latter date would be the date for inclusion in income.

59. INT. REv. CoDE of 1954, $\$ 317$ (a) ; U.S. Treas. Reg. $\$ 1.317-1$ (1955).

60. (Emphasis added.) The regulations also expressly recognize the statutory inclusion of this kind of taxable stock right within the meaning of "property," by referring to stock or rights to acquire stock of the distributing corporation "treated as property under section 305(b)"; and they prescribe that the amount of a distribution shall be the fair market value of "such obligations, stock, or rights." U.S. Treas. Reg. $§ 1.301$ (d) (1955) (dealing with distributions of property to corporate distributees).

61. See page 1025 sthra; Bittker, Stock Dividends, Distributions in Kind, Redcmplions and Liquidations Under the 1954 Code, 1955 U. So. CALrF. TAX INST. 349, 357. The draft of the American Law Institute made specific provision that the distribution of rights not qualifying for the exclusion shall be treated as a dividend distribution, but that the excrcise shall not be so treated nor otherwise result in gain or loss. 2 ALI FEd. Income TAX STAT. $\S \S \times 511$ (c) (1), (c) (3) (Feb. 1954 Draft).

62. See Bittker, supra note 61 , at 357. 
of stock rights prevents the shareholder from receiving a taxable interest upon the issuance, it also seems to repudiate the judicial requirement of corporate intention to make a distribution. The statute now provides a simpler and more objective test-has the corporation in fact made a distribution of property to the shareholders under section 301? "Distribution," not expressly defined, is used in context to describe an actual transfer of propenty by the corporation to the shareholders, and, as already seen, stock rights in shares of either the issuing or another corporation are embraced within the statutory pattern.

Under the most plausible reading of the statute the taxable event occurs when stock rights are first made available to the shareholders. What a court would actually decide remains a matter of conjecture, since no cases or rulings have yet considered the taxability of stock rights under the 1954 Code. ${ }^{63}$ When the issue arises courts should repudiate the Palmer dictum that no income is realized upon issuance of stock rights.

\section{Expiration of Rights Without Exercise or Sale}

Under the case law prior to the 1954 Code, stock rights did not produce income in the absence of their exercise or sale; therefore no loss was realized upon their forfeiture by lapse. ${ }^{64}$ Neither the 1954 Code nor the regulations speaks directly to the point on the effect of lapse. ${ }^{65}$ Undoubtedly the rule disallowing loss upon lapse continues to be applicable in all cases in which stock rights are not taxed as income. But if it should be held under the 1954 Code that the time for realization of income from a taxable distribution of stock rights is upon receipt, the reason for continued disallowance of a loss upon lapse would disappear. When the lapse occurs, the taxpayer would suffer a real loss, which should be allowed at the fair market value of the rights returned as income. ${ }^{08}$

63. But sec 1956 INT. Rev. BuLI. No. 46, at 8. A proposed issue to shareholders of package rights (to buy in a single package one share of common stock, together with one stock purchase warrant permitting the holder to buy an additional share at set prices within a period of years) would be non-taxable upon either issuance or the exercise by reason of $\S 305$ (a).

64. Eastern Shares Corp., 32 B.T.A. 608 (1935); St. Louis Union Trust Co., 30 B.T.A. 370 (1934) ; G.C.M. 25063, 1947-1 Cum. BuLL. 45. The rule is of course different when a third party purchased the rights, warrants or options for a consideration, and sustains a loss by expiration. 4 CCH 1957 Stand. Fed. TaX Rep. I 4742.05. See Sidney Z. Mitchell, 18 B.T.A. 994 (1930), aff'd, 48 F.2d 697 (2d Cir. 1931) (10 years "option warrants" which came attached to notes purchased by shareholder). For treatment of loss, see note 66 infra.

65. U.S. Treas. Reg. $\S 1.307-1$ (a) (1955), with regard to allocation of the basis of non-taxable stock rights in the issuing corporation, states that the general rule of allocation whall apply with respect to stock rights only if the rights are exercised or sold. This is consonant with disallowance of losses upon expiration without exercise or sale. The American Law Institute draft provided specifically against allowing loss upon lapse of non-taxed rights, but also allowed the basis of the stock to be increased by the amount of the basis of the rights. 2 ALI Fen. Income Tax Stat. $\$$ x511(a) (5) (Feb. 1954 Draft).

60. Since stock rights would normally constitute capital assets in taxpayer's hands, see Insull v. Commissioner, S7 F.2d 648, 650 (7th Cir. 1937), a capital loss would result. 


\section{Allocation of Basis Betzeen Stock and Non-Taxable Rights}

When a corporation makes a non-taxable distribution of rights to buy its own stock under section 305 of the 1954 Code, the basis of those rights is determined by allocating the adjusted basis of the underlying stock between the stock and the rights. ${ }^{67}$ When rights are exercised, the basis allocated to the rights is added to the subscription price to form the basis of the new stock. ${ }^{68}$ The basis allocated to the rights, and to the newly subscribed stock, becomes important in determining gain or loss upon a later sale of the rights or of the new stock.

The method of allocating basis outlined in the 1954 Code is substantially the same as in the 1939 Code, ${ }^{69}$ with a single exception. ${ }^{70}$ But the new regu-

The American Law Institute draft provided that loss caused by expiration of rights not exempted from taxation should be allowed subject to the limitations of the worthless securities section. ALI Fed. Income Tax Stat. $\$ x 511$ (c) (5) (Feb. 1954 Draft). The 1954 Code, in the worthless securities provision, specifically provides that the term "security" for purposes of the subsection includes "a right to subscribe for . . . a share of stock in a corporation," and that the loss resulting when a security constituting a capital asset becomes worthless shall be treated as a loss from the sale or exchange of a capital asset on the last day of the taxable year. INT. Rev. CoDE of 1954, $\$ 165$ (g) (2) (B). This section clearly should apply when stock rights become worthless, and their expiration should establish the fact of worthlessness. It seems likely that the general provision of $\$$ 1234 , providing that a loss upon failure to exercise a privilege or option to buy or sell property shall be treated as if the property had been sold or exchanged on the day the option expires, would give way to the worthless securities provision. See Montgourerr, Federal TAXES $\$ 11.3$ (35th ed. 1954) ("stock options ... are not stock rights"). But see $4 \mathrm{CCH}$ 1957 Stand. Fed. TAX Rep. If 4742.07 ("stock rights are another form of option or privilege" to which $\$ 1234$ would apply). If $\$ 1234$ applies, the taxpayer's holding would end upon the date the rights were allowed to expire.

67. INT. Rev. CoDE of 1954, $\$ 307$ (a). The American Law Institute proposed a different rule for allocation-the basis of rights sold without a sale of the stock would be zero, in the absence of an election by the taxpayer to allocate; but if the rights were exercised or the stock itself sold, allocation was made. 2 ALI Fed. Income Tax Stat. $\$$ x511(b) (Feb. 1954 Draft).

68. See example in U.S. Treas. Reg. $\$ 1.307-1$ (b) (1955).

69. Int. Rev. Code of 1939, § 113 (a) (19) (A), 53 Stat. 872; U.S. Treas. Reg. 118, $\S \S 39.22$ (a) -8 (b) (1-2), 39.113(a) (19-1) (1953); Edgar J. Hesslein, 21 B.T.A. 61 (1930), aff'd, 53 F.2d 1081 (2d Cir. 1931) (apportionment question arising upon later sale of original stock upon which rights were received by shareholder upon reorganization); Ayer v. Blair, 25 F.2d 534 (D.C. Cir. 1928) (allocation between old stock and new stock acquired through exercise of rights).

The exceptions to the general rule of allocation laid down by $\$ 113$ (a) (19) of the 1939 Code (subdivisions (B), (C) and (D)) are designed to protect the taxpayer and the government where past mistakes about the basis of the old stock, the new stock or rights issued upon the old stock had been made upon sale. Thus provision was made for the retention of the original basis of the old stock where the taxpayer without allocating had already included the entire proceeds of sale of rights (or stock) as a dividend, as he was once permitted to do. These specialized provisions concerning basis under previous laws are continued in INT. Rev. CoDE of 1954, \$ 1052(c). See 3 Mertens, Federal Incone Taxation $\$$ 21.146-21.150 (Supp. 1956) ; Alvord \& Biegel, Basis Provisions for Stock Dividends under the 1939 Revemue Act, 49 YALE L.J. 841 (1940). For 
lations prescribe that the allocation of the basis of the original stock shall be between the stock and rights in proportion to the fair market values of each, as of the date of distribution. ${ }^{71}$ And the date of distribution is not the record date, but the date the rights are distributed to the shareholder, a change from prior practice. ${ }^{72}$ Thus for purposes of allocation the time of distribution is necessarily when the rights are actually delivered to the shareholder. A comparable usage has already been suggested under sections 301 and $305 .{ }^{73}$

Allocation is of course unnecessary when taxable distributions of stock rights are made. The basis of the original stock then remains the same, and the basis of the rights is their fair market value, returned as income when received. ${ }^{74}$

\section{Holding Periods}

Consistent with the allocation of basis provisions, the holding period of the rights, under the 1954 Code, includes the time during which the taxpayer held the stock giving rise to the rights. ${ }^{75}$ The same rule applies whether or not the basis is allocated under section $307 . .^{76}$ A shareholder selling rights distributed less than six months before sale thus gains a substantial advantage through being able to tack on the period for which he has held the underlying stock. The holding period for the new stock, on the other hand, runs only from the date the rights were exercised. ${ }^{77}$ Neither the taxability of the rights nor the necessity of allocating part of the old stock's basis to the new stock affects computation of this holding period. ${ }^{78}$ Before this statutory solution case law

allocation questions relating to shares and warrants issued upon reorganization, see William T. Piper, 5 T.C. 1104 (1945) ; Bancitaly Corp., 34 B.T.A. 494 (1936).

In addition to allocation questions, questions of identification of the property sold could also arise upon sale of a portion of the rights or stock acquired through their excrcise. Such questions are determinable under the usual presumption of first-in first-out. See U.S. Treas. Reg. 118, $\$ \$ 39.22$ (a) $-8($ b) (3), 39.113(a) (12)-1 (1953).

70. When the value of the rights is less than $15 \%$ of the fair market value of the stock at the time of distribution, basis need not be allocated. INT. REv. Cone of 1954, $\$$ 307 (b). The purpose of this exception is to relieve the taxpayer from the burden of complex calculations of basis when the value of the rights distributed is relatively small in relation to the total investment.

71. U.S. Treas. Reg. \$1.307-1 (a) (1955).

72. Ibid. For prior practice see I. T. 2509, VIII-2 Cum. Bull. 78 (1929); I. T. 2474, VIII-1 Cum. Bulz. 65 (1929) ; G.C.M. 1394, VI-1 Cux. Bull. 35 (1927).

Use of distribution rather than record date has been criticized for creating administrative difficulties in taxation of stock rights. 2 CCH 1957 FED. TAX SERv., If 2346.01.

73. See text at note 57 supra.

74. See U.S. Treas. Reg. $\$ 1.307-1$ (a) (1955) ; U.S. Treas. Reg. $118, \$ 39.22$ (a) -8 (b) (1953).

75. INT. REV. CoDE of 1954, \$ 1223(5).

76. The basis would be "determined under section 307 ," as that language is used in $\$ 1223$ (5). Section 305 was recently interpreted in 1956 INT. REv. BuLl. No. 46, at 8. The corresponding 1939 Code provision was $\$ 117(\mathrm{~h})(5)$, with U.S. Treas. Reg. 118, $\S$ 39.117 (h) -1 (b) (1953).

77. INT. Rev. CoDE of 1954, \$ $1223(6)$.

78. Int. Rev. Code of 1939, \$ $117(\mathrm{~h})(6), 53$ Stat. 873 (now INr. Rev. Code of 
divided stock purchased by the exercise of rights into constituent elements to determine holding periods: (1) the stock right element, which was governed by the date of acquisition of the original stock; and (2) the subscription price element, controlled by the date of exercise. ${ }^{79}$ Under this method the same stock might be allocated to different holding periods; not uncommonly stock could be purchased through exercise of a series of rights issued at different times. The present solution eliminates inconvenient calculations and administrative complications without great inequity, since normally the greater part of the actual basis is in the subscription price rather than the rights. ${ }^{80}$ The present rules determining the holding periods of non-taxable stock rights and of new stock acquired upon their exercise have been applied in a recent Treasury ruling. ${ }^{81}$

Consistency would require that the holding period for taxable stock rights run from the time of distribution, when their value for taxation and their future basis is determined.

\section{Effect Upon Earnings And Profits of Distributing Corporation}

Under the 1954 Code non-taxable stock rights do not result in a distribution of earnings and profits of the distributing corporation. ${ }^{82} \mathrm{By}$ negative inference a distribution of taxable stock rights should result in a reduction of

1954, $\$ 1223(6)$ ) ; U.S. Treas. Reg. 118, § 39.117(h)-1c (1953). Montgomery, Federal TAXES $\$ 11.3$ (35th ed. 1954).

79. Insull v. Commissioner, 87 F.2d 648 (7th Cir. 1937) ; Wood v. Commissioner, 75 F.2d 364 (1st Cir. 1935) ; Walter Fitch, Jr., 35 B.T.A. 537 (1937) ; G.C.M. 22647, 1941-1 Cum. Bull. 381; see Macy v. Helvering, 82 F.2d 183 (2d Cir. 1936).

S0. 3 Mertens, Federal Incone Taxation $\$ 22.34$ (Supp. 1956) ; H.R. Rep. No. 2333, 77th Cong., 2d Sess. 98 (1942).

81. Rev. Rul. 56-572, 1956 INT. Rev. Burc. No. 46, at 8, in which package rights to subscribe both to additional stock and stock purchase rights were issued to shareholders pro rata. If the shareholder sold, the holding period of the package rights dated from the acquisition of the original stock. But if by the exercise of the package rights the shareholder acquired new stock and stock purchase rights, the holding period of both the stock and of the stock purchase rights so acquired was held to run from the date of exercise under $\$ 1223(6)$. In addition, the holding period of new stock acquired through the exercise of stock purchase warrants would not begin until the date of exercise of the warrants.

82. INT. REv. CoDE of 1954, $\$ 312$ (d). This is specifically applicable to stock rights in shares of another corporation as well as to shares in the distributing corporation's stock. U.S. Treas. Reg. $\$ 1.312-1$ (d) (1955) provides:

"In the case of a distribution of stock or rights to acquire stock a portion of which is includible in income by reason of section $305(\mathrm{~b})$, the earnings and profits shall be reduced by the fair market value of such portion. No reduction shall be made if a distribution of stock or rights to acquire stock is not includible in income under the provisions of section 305."

Sections 312 (d) (1) (A) and (B) specifically cover distributions by the corporation of either its stock or securities or stock or securities in another corporation if gain to the distributee is not recognized upon receipt under the Code. Further, for purposes of the subsection the term "stock or securities" includes rights to acquire stock or securities. 
the earnings and profits account of the corporation. The statutory definition of "property" 83 does not include stock or stock rights in the issuing corporation. And only the distribution of "property" will result in a decrease in the earnings and profits account. ${ }^{84}$ Nevertheless the regulations support the interpretation that the earnings and profits shall be reduced by the fair market value of distrihuted rights to acquire stock includible in a shareholder's income under section 305 (b).$^{85}$ The same result should follow, when rights to acquire the stock of anther corporation are distributed-a result which has been reached in the absence of specific statutory provision under the 1939 Code. ${ }^{86}$

Moreover, the choice of time of issuance to the shareholder would simplify the bookkeeping problems of the corporation. The time for adjustment of earnings and profits presently seems to depend upon whether the taxable event results from the issuance or exercise of the rights. If no taxable event occurs until a subsequent exercise or sale of the rights, the corporation would be forced to postpone its earnings and profits adjustment, for more than a year in some cases. The result would be especially confusing for large corporations since their many shareholders might sell or exercise at different times. As a practical matter, compliance with the Code requirements for earnings and profits adjustments necessitates adoption of the date the rights are issued to the shareholders as the distribution date.

\section{Tax Consequences for The Corporation}

Of course a corporation does not realize taxable gain or loss by a distribution of stock rights to the stockholders. ${ }^{87}$ But the question of the taxability and time of taxability of stock rights to the shareholders may be of importance to the corporation since the dividends paid deduction under the accumulated earnings tax depends upon a dividend paid. ${ }^{88}$ If the rights are taxed as dividends to the stockholders under section 316 , deduction by the corporation will be allowed to the extent of their fair market value. ${ }^{89}$

\section{Stock Rights As Section 306 Stock}

If stock rights are not taxed as income when distributed, by reason of section 305 (a), they are treated, under section 306 , "as stock distributed at the time

83. Int. Rev. Cone of 1954, $\$ \$ 312$ (a), 317 (a).

84. Only the amount of the "adjusted basis" can be used in making the reduction. Id. $\$ 312(a)(3)$.

85. See U.S. Treas. Reg. 1.312-1 (d) (1955).

36. W. G. Maguire \& Co., 20 T.C. 20 (1953).

87. INT. Rev. Code of 1954, \$ 311(a). See S. Rep. No. 1622, 83d Cong., $2 d$ Sess. 247 (1954) e:slaining that this provision, new in the 1954 Code, incorporates the general rule of certain court decisions that the corporation realizes no gain or loss upon a distribution of property to its shareholders. See also General Util. \& Operating Co. v. Helvering, 296 U.S. 200 (1935).

83. Inv. Rev. Cone of 1954, $\$ \$ 531-537$.

S9. Id. \$ 562. And see U.S. Treas. Reg. 1.18, \$ 39.27 (f) (1) (1953).

\%. See text at note $\mathbf{5 5}$ supra. 
of the distribution of the stock rights."91 Through such treatment stock rights, as well as stock acquired through their exercise, may later be subject to ordinary income taxation upon redemption or disposition, but only to the extent of the fair market value of the rights at the time of the distribution. ${ }^{92}$ The regulations agree that the amount to be given ordinary income tax treatment upon subsequent disposition of the rights, or of stock acquired by the exercise of the rights, is determined by reference to the date of distribution of the rights. ${ }^{93}$

\section{Stock Rights as "Stock Or Securities" Under Reorganization Provisions}

For purposes of the statutory dispensations providing for non-recognition of gain or loss in connection with the receipt of stock or securities upon a transfer to a controlled corporation ${ }^{94}$ and upon certain exchanges of stock or securities in corporate reorganizations of both the combinative ${ }^{95}$ and divisive ${ }^{80}$ types, the applicable Regulations all prescribe that "stock rights or stock warrants are not included in the term 'stock or securities.' "97 Therefore, stack rights or stock warrants received would constitute "other property" treated as boot under section 356,98 and the fair market value of the gain would be taxed as a dividend to the extent of the shareholder's ratable share of the undistributed earnings and profits of the corporation. ${ }^{99}$

\section{CONCLUSION}

Courts should accept the opportunity given them by the 1954 Code to hold receipt of taxable stock rights the taxable event. In so doing, they can eliminate the difficulties caused by illogical principles developed in past decisions. Treating stock rights as a distribution in the amount of their fair market value at the time of issuance would follow the established pattern for taxation of other valuable property. And the consistent practice in valuation of the taxable amount at the one date of issuance would greatly simplify the corporation's task in keeping current its earnings and profits accounts.

91. Int. Rev. Code of 1954, \$\$ 306(c) (1) (A), 306(d) (2). Cf. 2 ALI FEd. Inconse TAx Star. $\$ \S \times 511(a)(3)(B), x 511$ (a) (4) (Feb. 1954 Draft).

92. U. S. Treas. Reg. $\$ 1.306-3$ (b) (1955). The rights will not be $\$ 306$ stock if no part of the distribution would have been a dividend if money had been distributed in lieu of the rights. This situation would occur when the corporate earnings and profits account is insufficient to cover the distribution.

93. U.S. Treas. Reg. $\$ 1.306-3$ (b) (1955).

94. INT. REv. CODE OF 1954, § 351 .

95. Id. $\S \S 354,368$.

96. Id. $\$ 355$.

97. U.S. Treas. Reg. \$\$ 1.351-1(a) (1), 1.354-1(e), 1.355-1 (a) (1955).

98. See INT. Rev. CoDE of 1954, $\$ 351$ (b), 354(a) (3), 355(a) (4), 356. Previous cases in accord: James F. Curtis, 3 T.C. 648, 659 (1944) ; Margaret Weston, P-H 1941 B.T.A. Mem. Dec. If 41046, appeal dismissed pursuant to stipulation, 135 F.2d 738 (8th Cir. 1943). But cf. William T. Piper, 5 T.C. 1104 (1945); E. P. Raymond, 37 B.T.A. 423 (1938) ; Bancitaly Corp., 34 B.T.A. 494 (1936).

99. INT. Rev. CoDE of 1954, \$\$356(a) (1) (B), 354. Section 356(b) provides that, if $\$ 355$ would apply but for the fact that the distribution consists also of other property, the other property "shall be treated as a distribution to which section 301 applies." 


\section{THE YALE LAW JOURNAL}

\author{
Arthur L. Lingan \\ StepHen A. WeIner \\ Comment Editors
}

Matthew T. Adans

Malvin E. Bank

JoHN W. BARNUM

Thomas D. BarR

WILLiam C. BAskin, JR.

ROBERT T. Basseches

FREDERICK L. BERNSTEIN

Neil N. Bernstein

David P. Bicrs

Judith MYra Bleich

Newton D. Brenner

Guido Calabresi

Laura M. Chaparan

Paul H. DeCoster

Robert J. DeL Tufo

Milton P. DeVane
ROBERT W. BLANCHETTE

Editor-in-Chief

H. E. DUNkelderger, JR. RODNEy E. Eyster

Article and Book Revieres Editor

Alvin Friedman

Note Editors

AXEL H. BAUM

IIanaging Editor

John Richard Duffield

Williak L. F. FeLstiner

Arthur Fleischer, Jr.

Gerald T. FloM

Gerald A. Fox

Seth E. Frank

VICTOR S. FRIEDMAN

Morton I. Greenbera

Mímton S. Gwirtzman

Alan M. Hofmian

Alan J. Hruska

William E. Huth

Lloyd J. Keno

David KingsBerg

HAROLD S. LEVY

IRWIN A. LEVY

JuLIUS LEwIS

RICHARD MARLIN

Richard M. MEYer

JerRold L. Morgulas

Huge G. MoultoN

WALTER W. OberRett

Richard W. Pendleton, Jr.

BURTON RAFFel

JEROME HowARD REICHMAN

Richard J. Sexton

STEPHEN N. SHuLMAAN

LEWXS A. STERN

Charles W. Thomasson

Stanley E. Tobin

FrANK E. G. WEII

ROBERT L. WEINBERG

Marte McMahon

Business Secretary

\section{CONTRIBUTORS TO THIS ISSUE}

Elias Clark. Associate Professor of Law, Yale Law School. Member of the Connecticut and New York Bars.

Frederick W. Whiteside, JR. Professor of Law, University of Kentucky. Graduate Fellow, Yale Law School, 1956-57. Member of the Arkansas, Kentucky, New York and Supreme Court Bars. 